\title{
Social Media Exploration 1.1
}

\section{Te Kahu Rolleston}

tekahu@wclc.org.nz

He uri tēnei mai i ngā tai e papaki tu ana ki mauao, no te ia moana o te awanui, te ia-auraki o Tauranga ka rere i te ao ka rere i te po. Ko Ngaiterangi te iwi, ko ngā moutere whakaruruhau o Matakana ngā turangawaewae ōku. Koira te pūtake o tōku tāngaengae. Tauranga Moana Tauranga Tangata.

I descend from the tides that crash and break against my ancestral mountain named Mauao. I am of the great running currents of my sea fearing people, The Vein of our lives, Te Awanui. The islands of Matakana are where I plant my feet and call home. That is my very foundation from where I will always draw life. Tauranga's sea, and Tauranga's people are one.

We have come from surfing waves,

to surfing the web,

We used to catch fish in our nets,

now people catfish the Internet.

Undiscovered and unknown are the depths of this new sea.

A new space, for exploration,

but what does that really mean?

For my Iwi, for my tribe,

for Natives and First Nations worldwide?

Our hands are bound,

shackled to keyboards tied.

As Internet speeds fall and rise

with the importance of the tides.

Will we drown in these currents,

In our attempt to keep up with what's current?

Who knows!

It's for us, the first generation,

of Indigenous digital Natives, to explore the space,

to ensure it's navigated in a way, which is culturally safe.

I need to know, before the end of my time,

How will the net and social media impact my sacred traditional Marae?

Because like it or not,

don't ask why for, Wi-Fi is here on lock like hotspots.

People often ask me, how do you get people online to engage with your words?

I call those people lone bulls because they just want to be herd.

But I tell them the first thing you need to understand,

is your social media reach and span.

That can be your friend list, of if you have a group or band,

it means finding how hot or cold are the cycles of your fans.

Then you can start viewing it from people's perspectives, making it easier to get at em.

Over time, you will be able to roughly predict peoples posting patterns and online habits. 
Something cool about groups pages that's pretty wicked, is they actually give you a breakdown of a pages statistics.

So you know which posts get the most activity, on what day, at what time do you get the most traffic visiting.

From here you can determine what's optimum posting time!

If you want people to see what you post, then post, what you post when more people are online.

Basically I've found the key that works best for me, for the amount of people your posts reach is timing, and aligning it with when people are in front of the screen.

In my opinion there's 2 more secrets, one, is a network to share your stuff so it keeps reaching. Secondly the content of what you're speaking.

Speak your truth, that's how you set movements in movement.

That's why I speak 100 to the power of word, I frack into souls like digging on a mineral search, so I may speak to people's hearts.

Art, is not the reason for these words I chisel and carve, these words that I carve, offer a voice to those who have something to say but cant.

The wood is people's thoughts, the chisel both my finger tips typing and tongue.

The mallet swings with a tap on the enter tab, or the shift of my lung.

Social media allowed this to happen, now people read my words online.

I'm suddenly a powerful poet with passion, they used to write me off as a darky.

Now I'm that Native that inspires and educates the masses, using his talent and gift for good, while weaving poetry and rapping.

Biggie told us it was all a dream,

But Chris Brown told us it was all a tweet.

Copyright: (C) 2017 Rolleston. This is an open-access article distributed under the terms of the Creative Commons Attribution-NonCommercial 3.0 Australia License, which permits noncommercial use, distribution, and reproduction in any medium, provided the original author and AJIS are credited. 


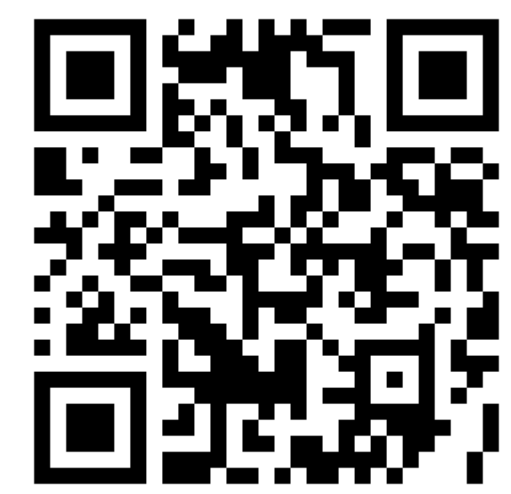

